\title{
Asemptomatik Olgularda COViD-19 Prevalansı, Acil ve Ertelenemeyen Cerrahi Planlanan Çocuklarda Komplikasyon Gelişimine Etkisi
}

\author{
The Prevalence of COVID-19 in Asymptomatic Cases and Its \\ Effect on Complication Development in Children Scheduled for \\ Emergency and Urgent Surgery
}

Müjdem Nur AZILII,2, Can İhsan ÖZTORUN ${ }^{1,2}$, Emel Elif ERTEN², Doğuş GÜNEY1,2, Ahmet

ERTÜRK², Gülsen KESKIN³, Ayşe ERTOY², Abdurrahman Urve UZUN², Süleyman Arif BOSTANCl'2, Aslınur ÖZKAYA PARLAKAY4,5, Emrah ŞENEL ${ }^{1,2}$

\author{
${ }^{1}$ Yıldırım Beyazıt Üniversitesi, Tıp Fakültesi, Çocuk Cerrahi Anabilim Dalı, Ankara, Türkiye \\ ${ }^{2}$ Ankara Şehir Hastanesi, Çocuk Hastanesi, Çocuk Cerrahi Kliniği, Ankara, Türkiye \\ ${ }^{3}$ Ankara Yıldııım Beyazıt Eğitim ve Araştırma Hastanesi, Anestezi ve Reanimasyon Kliniği, Ankara, Türkiye \\ ${ }^{4}$ Yıldıım Beyazıt Üniversitesi, Tıp Fakültesi, Çocuk Sağlığı ve Hastalıkları Anabilim Dalı, Çocuk Enfeksiyon Bilim Dalı, Ankara, Türkiye \\ ${ }^{5}$ Ankara Şehir Hastanesi, Çocuk Hastanesi, Çocuk Enfeksiyon Kliniği, Ankara, Türkiye
}

\section{ÖZ}

Amaç: Çocukluklarda COVID-19 sıklıkla asemptomatik ya da daha selim bir seyre sahip olsa da temas riskinden dolayı sağlık çalışanlarının güvenliği asıl hedef olmalıdır. Çalışmamızda hem hasta hem ameliyathane hem de sağlık çalışanlarının iş güvenliğine ışık tutacak acil ve ertelenemeyen cerrahi olgularında asemptomatik COVID-19 PCR pozitifliğini araştırmayı amaçladık.

Gereç ve Yöntemler: Çalışmamız pandemi hastanesine dahil çocuk hastanesinin çocuk cerrahisi kliniğine acil ve ertelenemeyen cerrahi nedenler ile başvuran 18 yaş altı olgular için tasarlanmış olup ileriye dönük yapılmış tek merkezli bir çalışmadır. Çalışmaya Mayıs 2020 -Ekim 2020 tarihleri arası altı aylık izlemde acil ve ertelenemeyen cerrahi yapılan olgular dahil edildi. Belirtilen tarihler arasında başvuran 458 hasta değerlendirildi ve kriterleri karşılayan 433 hasta çalışma kapsamında değerlendirildi. olgulardan preoperatif muayene ve tetkik esnasında COVID-19 için nazofaringeal sürüntü (PCR) örneği alındı.

Bulgular: Çalışmaya dahil edilen 433 olgunun 155'i kı (\%33.5), 278'i (\%66.5) erkekti. Yaş ortalaması 9.5 yıl olarak hesaplandı. Acil vakaların tüm olguların 389'unu (\%89.8) oluşturduğu saptandı. Yaş gruplarına göre en sık acil patolojilerin; yenidoğan döneminde intestinal obstrüksiyon veya atreziler, okul öncesi dönemde solunum yoluna yabancı cisim aspirasyonlar, okul çağında akut apandisit olduğu görüldü. Nazal sürüntü PCR sonuçları sadece dört hastada pozitif bulundu, bu oranın tüm çalışma grubunda \%0.9 olduğu görüldü, bu olguların hiçbirinde postoperatif komplikasyon ve sağlık çalışanına bulaş saptanmadı.

(1)

AZILI MN

ÖZTORUNCI

ERTEN EE

GÜNEY D

ERTÜRK A

KESKIN G

ERTOY A

UZUNAU

BOSTANCI SA

ÖZKAYA PARLAKAY A

ȘENELE
Çıkar Çatışması / Conflict of Interest: Tüm yazarlar adına, ilgili yazar çוkar çatıșması olmadı̆ğıı belirtir.

: 0000-0002-5137-7209 $0000-0002-5408-2772$ 0000-0002-3666-295X 0000-0001-7168-2123 0000-0002-8156-5665 0000-0002-9990-5533 0000-0002-3129-0130 $0000-0002-4649-8700$ :0000-0002-7512-3895 $0000-0001-5691-2461$ $0000-0002-0383-4559$

Etik Kurul Onayı / Ethics Committee Approval: Bu çalışma Helsinki Deklarasyonu Illkelerine uygun olarak yapılmıştır. Çalışma için Ankara Şehir Hastanesi, 1. Nolu Klinik Araştırmalar, Etik Kurulu'ndan 02.09.2020 /2020-E1-20-955 numaralı onay alınmıştı

Yazarların katkısı / Contribution of the Authors: AZILI MN: Araștırma ve/veya makalenin hipotezini veya fikrini olușturan, Sonuçlara ulașmak çin planlama/metodoloji belirleme. Hasta takibinde sorumluluk almak, ilgili biyolojik malzemelerin toplanması, veri yönetimi ve raporlama, deneylerin yürütülmesi, Sonuçların mantıksal olarak Yorumlanması ve sonuçlandırılması, Calıșma için gerekli literatür taramasında sorumluluk almak, Calıșmanın bütününün veya önemli bölümlerinin yazımında sorumluluk almak. ÖZTORUN Ci: Sonuçlara ulaşmak için planlama/metodoloji belirleme, Çalsşma için gerekli literatür taramasında sorumluluk almak, Çalışmanın bütününün veya önemli bölümlerinin yazımında sorumluluk almak. ERTEN EE: Sonuçlara ulașmak için planlama/metodoloji belirleme, Çalıșmanın bütününün veya önemli bölümlerinin yazımında sorumluluk almak. GÜNEY D: Araștırma/ çalıșmanın sorumluluğunu üstlenmek, ilerlemenin seyrini denetlemek. ERTÜRK A: Araștırma/çalışmanın sorumluluğunu üstlenmek, ilerlemenin seyrin denetlemek, Hasta takibinde sorumluluk almak, ilgili biyolojik malzemelerin toplanması, veri yönetimi ve raporlama, deneylerin yürütülmesi. KESKiN G: Araștırma/çalıșmanın sorumluluğunu üstlenmek, ilerlemenin seyrini denetlemek. ERTOY A: Hasta takibinde sorumluluk almak, ilgili biyolojik malzemelerin top̉nmaç, vöintimi ve raporlama, deneyl,

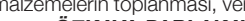
A: Çalıșma için gerekli literatür taramasında sorumluluk almak, Yazım ve dilbilgisi dıșinda bilimsel olarak gönderilmeden önce makaleyi gözden geçirme. ŞENEL E: Yazım ve dilbilgisi dışında bilimsel olarak gönderilmeden önce makaleyi gözden geçirme.

Atıf yazım șekli / How to cite : Azllı MN, Öztorun Cl, Erten E, Güney D, Ertürk A, Keskin G ve ark. Asemptomatik Olgularda COVID-19 Prevalansı ve Acil ve Ertelenemeyen Cerrahi Planlanan Cocuklarda Komplikasyon Gelișimine Etkisi. Türkiye Cocuk Hast Derg 2021;15:415-419.
Geliş tarihi/ Received : : 16.08.2021 Kabul tarihi / Accepted : 07.09.2021 Elektronik yayın tarihi : 10.09 .2021 Online published

DOI: 10.12956/tchd.983312 
Sonuç: Bu prospektif çalışma ile acil veya ertelenemeyen cerrahi planlanan asemptomatik çocuklarda düşük COVID-19 PCR pozitifliği (\%0.9 prevalans) tespit edilmiş olup güvenli prosedür uygulamalarının planlanmasına ışık tutacağı kanaatindeyiz.

Anahtar Sözcükler: Asemptomatik, Cerrahi, Covid 19, Komplikasyon, PCR

\section{ABSTRACT}

Objective: Although COVID-19 in childhood is often asymptomatic or has a more benign course, the safety of healthcare workers should be the primary goal because of the risk of contamination. In our study, we aimed to investigate the asymptomatic COVID-19 PCR positivity and its effect on the development of complications in emergency and non-deferred surgery cases that will help both the patient, the operating room and the health care workers.

Material and Methods: This is a prospective study that was performed in patients under 18 years of age who were operated on due to emergency and urgent cases in the Ankara City Children's Hospital, which was serving as an anti-pandemic hospital. The patients were evaluated from May 1 to October 1, 2020. Of the 458 patients, 433 patients who met the criteria were included in the study. COVID-19 Nasopharyngeal swab (PCR) samples were taken from all patients along with preoperative examinations.

Results: Of the 433 cases included in the study, 155 (33.5\%) were girls and 278 (66.5\%) were boys. It was determined that emergency cases constituted 389 (89.8\%) of all cases. The most common emergency pathologies according to age groups were intestinal obstruction or atresia in the neonatal period, foreign body aspirations of the respiratory tract in the preschool period, and acute appendicitis in the school age. Nasal swab PCR results were positive in only four patients, this rate was found to be $0.9 \%$ in the entire study group, and postoperative complications and transmission to healthcare workers were detected at none.

Conclusion: In this prospective study, low COVID-19 PCR positivity (0.9\% prevalence) was detected in asymptomatic children scheduled for emergency or non-deferred surgery, and we believe that it will shed light on the planning of safe procedure practices.

Key Words: Asymptomatic, Surgery, Covid 19, Complication, PCR

\section{Giriş}

Mart 2020 tarihinden itibaren Coronavirüs-2019 Hastalığının (COVID-19) pandemi olarak kabulü günlük hayatımızda birçok rutinimizi değiştirmiştir (1). Çocukluklarda COVID-19 sıklıkla asemptomatik ya da daha selim bir seyre sahip olsa da temas riskinden dolayı sağlık çalışanlarının güvenliği asıl hedef olmalıdır. Pandemi sürecinde çocuk cerrahları da alışılagelmiş cerrahi girişim planlanmasında yeni düzenlemelere intiyaç duymuştur. Pediatrik olguların triyajına yönelik yayınlanan COVID-19 kılavuzları; hastane kaynaklarının uygun kullanımı ve sağlık çalışanlarının korunması amacı ile en yaygın cerrahi patolojileri; acil, ertelenmeyen ve elektif girişimler olmak üzere üç kategoriye ayırmıştır (2). Çalıştığımız hastanenin büyük bir pandemi hastanesi olmasının yanı sıra acil cerrahi patolojilerin tedavisine devam edilme zorunluluğu, güvenlik şartlarının sağlanması koşuluyla acil ve ertelenemeyen işlemlere devam edilmesine neden olmuştur. Çalışmamızda hem hasta hem ameliyathane hem de sağlık çalışanlarının iş güvenliğine ışık tutacak acil ve ertelenemeyen cerrahi olgularında asemptomatik COVID-19 PCR pozitifliğini araştırmayı amaçladık.

\section{GEREÇ ve YÖNTEMLER}

Çalışmamız pandemi hastanesine dahil çocuk hastanesinin çocuk cerrahisi kliniğine acil ve ertelenemeyen cerrahi nedenler ile başvuran 18 yaş altı olgular için tasarlanmış olup ileriye dönük yapılmış tek merkezli bir çalışmadır. Çalışmaya Mayıs 2020 -Ekim 2020 tarihleri arası altı aylık izlemde belirtilen kriterleri karşılayan olgular dahil edildi. Belirtilen tarihler arasında başvuran 458 hasta değerlendirildi ve kriterleri karşılayan 433 hasta çalışma kapsamında değerlendirildi.

\section{Araştırmaya dahil olma kriterleri;}

a 0-18 yaș grubu çocuklarda tüm acil ve ertelenmesi sakınca yaratacak tümör ve benzeri olgular,

b Belirlenen kılavuzlara uygun COVID-19 belirtilerinin sorgulanmış ve kayda alınmış olması,

c COVID-19 ilişkili yakınmalar açısından asemptomatik olması,

d COVID-19 öyküsünün olmaması,

e Yakın zaman içinde aile içinde COVID-19 öyküsünün olması,

Araştırmaya almama veya araştırmadan çekilme kriterleri

a Önceden bilinen COVID-19 pozitifliği,

b COVID-19 belirtilerini taşıyan olgular,

c Elektif cerrahi planı olan olgular,

d Süreçte diğer nedenler ile ameliyat planından vazgeçilen olgular,

\section{Tanımlamalar ve klinik değerlendirme}

Pediatrik olguların triyajına yönelik yayınlanan COVID-19 kılavuzlarında; hastane kaynaklarının optimize edilmesi ve sağlık çalışanlarının sağlığının korunması amacı ile en yaygın cerrahi patolojiler üç kategoriye ayrılmıştır (2):

a Acil durumlar (gecikmesi halinde yaşamı tehdit eden),

b Ertelenemeyen durumlar (günler veya haftalarca ertelenirse zararlı),

c Elektif vakalar (gecikme durumunda hastalar için minimum risk). 
Çalışma kapsamında acil ve ertelenemeyen cerrahi nedeniyle çocuk cerrahi servisine yatırılan olgulardan preoperatif muayene ve tetkik esnasında COVID-19 için nazofaringeal sürüntü (PCR) örneği alındı. Tüm olgular kılavuzların önerdiği şekilde ateş, öksürük, burun akıntısı ve halsizlik yönünden sorgulandı. Ayrıca ailenin son iki hafta içinde COVID-19 tanısı alıp almadığı, yurt dışı ziyaret veya temas öyküsü araştııldı. Takip formları ile mevcut sorulara cevaplar kayıt altına alındı, șüphe durumunda olgular çalışma dışında bırakıldı. Aktif COVID-19 enfeksiyonu geçiren olgular çalışmaya dahil edilmedi. Çalışma için yerel etik ve Sağlık Bakanlığı izni alındı, çalışmaya dahil edilen tüm vakalardan bilgilendirme sonrası ebeveynlerinden çalışma için aydınlatıımış onam formu alındı (karar numarası 2020-E1-20-955). Acil ve ertelenmeyen cerrahi patolojiler nedeniyle çalışmaya dahil edilen olgular yaş gruplarına göre sınıflandı. Yenidoğan grubu; 0-28 gün, okul öncesi; 1 ay- 6 yaş, okul çağı 7 yaş ve üzeri çocukları içerecek şekilde planlandı. PCR pozitifliği cerrahi sebep ve yaş gruplarına göre değerlendirildi. Süreçte pozitif saptanan olgular çocuk enfeksiyon değerlendirmesi sonrasında izleyen branşların önerileri ve tedavileriyle takip edildi. Mevcut cerrahi prosedürlere ek olarak COVID-19 ilişkili istenmeyen sonuç ya da komplikasyon varlığı araştıııdı. Pozitif olgulara, cerrahi prosedür ve yatış süresince uygun koruma tedbirleri altında temas eden sağlık çalışanları COVID-19 ilişkili hastalık belirtilerinin gelişimi için takibe alındı. PCR tetkikinin kısıtı olması nedeniyle temas eden sağlık çalışanlarında rutin PCR taraması yapılmadı. Operasyona ve servis izlemine dahil olan sağlık personelinin bir ay içinde semptomatik olma durumunda PCR tetkiki yapılması, pozitif olması durumunda olası kontaminasyon yönünden değerlendirmeye alınması planlandı.

\section{BULGULAR}

Çalışmaya dahil edilen 433 olgunun 155'i kı (\%33.5), 278'i (\%66.5) erkekti. Yaş ortalaması 9.5 yll olarak hesaplandı. Yaş gruplarına göre bakıldı̆̆ında; 30 olgunun yenidoğan döneminde (\%6.9), 84 olgunun okul öncesi yaş grubunda (\%19.2), 319 olgunun ise okul çağında olduğu görüldü. Yedi yaş üstü olguların okul çağı olarak kabul edildiği ve \%73.9 oranı ile bu grubun en yoğun grup olduğu saptandı. Olguların cerrahi sebepleri, yaş, sayı ve en sık nedenleri acil ve ertelenmeyen ana başlıklarına göre tablo 1'de verilmiştir. Acil vakaların tüm olguların 389'unu (\%89.8) oluşturduğu ve ertelenmeyen vakaların daha nadir izlendiği saptandı. Yaş gruplarına göre en sık acil patolojilerin; yenidoğan döneminde intestinal obstrüksiyon veya atreziler, okul öncesi dönemde solunum yoluna yabancı cisim aspirasyonları ve okul çağında akut apandisitin olduğu görüldü. Ertelenemeyen sebepler olarak bakıldığında yenidoğan dönemine ait en sık patolojilerin özefagus atrezisi ve diyafram hernisi, okul öncesi grupta özefagus darlığı/ dilatasyon, gastrointestinal yabancı cisimlerin ve okul çağı grupta malignite ve özefagus darlığı/ dilatasyonun neden olduğu saptandı.

Nazal sürüntü COVID-19 PCR sonuçları dört hastada pozitif bulundu, bu oran tüm çalışma grubunda \%0.9 olarak tespit edildi. PCR pozitif saptanan hastaların tümü okul çağı yaş grubunda idi ve yaş ortalaması 10.7 olarak saptandı (7-14 yıl). Çalışmaya dahil edilme kriterlerine uygun şekilde pozitif olguların hepsi yakınma ve öykü değerlendirmesinde asemptomatikti. Pozitif olguların tümü akut apandisit nedeni ile başvurdu. Diğer yaş grupları olan yenidoğan ve okul öncesi olgularda PCR pozitifliğine rastlanmadı. Acil cerrahi grubunda olan dört hastanın ameliyatları erteleme yapılmadan PCR sonuçları bilinerek COVID-19 için ayrılmış ameliyat odasında gerçekleștirildi. Kişisel koruyucu ekipman ve tıbbi maskeler hem hasta hem de sağlık ekibi tarafından takılarak gerekli müdahaleler yapıldı. COVID-19 pandemisinin erken dönemlerinde yayınlanmış kılavuzların uyarınca laparaskopi ile bulaş riskinin olabileceği öngörüldüğü için apendektomiler laparatomi ile gerçekleştirildi (3). Tüm appendektomi materyalleri patolojik değerlendirmede akut apandisit ile uyumlu saptandı. Olguların postoperatif izlemde vital bulgularında herhangi bir patoloji izlenmedi. Ortalama yatış süreleri 3.6 gündü (2-3 gün). Takipte COVID-19 ilişkili veya primer cerrahi sebep ile ilgili komplikasyon saptanmadı. İzlem süresinde pozitif vakalar ile uygun koruma tedbirleri ile temas eden sağlık çalışanlarının hiçbirinde bir aylık izlemde COVID-19 enfeksiyonu ilişkili klinik saptanmadı.

Tablo I: Yaş ve cerrahi tipine göre PCR örneklerinin değerlendirilmesi.

\begin{tabular}{|c|c|c|c|c|c|c|}
\hline & n (\%) & Girişim çeşidi & Sayı & Nedenler (en sık) & Sayı & PCR (+) \\
\hline $\begin{array}{l}\text { Yenidoğan } \\
0-28 \text { gün }\end{array}$ & $30(7)$ & $\begin{array}{l}\text { Acil } \\
\text { Ertelenemeyen }\end{array}$ & $\begin{array}{l}18 \\
12\end{array}$ & $\begin{array}{l}\text { İntestinal obstruksiyon/ atrezi } \\
\text { İntestinal perforasyon } \\
\text { Özofagus atrezisi } \\
\text { Diafram hernisi }\end{array}$ & $\begin{array}{l}9 \\
3 \\
7 \\
3\end{array}$ & $\begin{array}{l}0 \\
0 \\
0 \\
0\end{array}$ \\
\hline $\begin{array}{l}\text { Okul öncesi } \\
1 \text { ay-6 yaş }\end{array}$ & 84 (19.3) & $\begin{array}{l}\text { Acil } \\
\text { Ertelenemeyen }\end{array}$ & $\begin{array}{l}65 \\
19\end{array}$ & $\begin{array}{l}\text { Yabancı cisim aspirasyonu/ Bronkoskopi } \\
\text { Appendisit } \\
\text { Özofagus darlığı/ dilatasyon } \\
\text { Gastrointestinal yabancı cisim }\end{array}$ & $\begin{array}{r}18 \\
16 \\
5 \\
4\end{array}$ & $\begin{array}{l}0 \\
0 \\
0 \\
0\end{array}$ \\
\hline $\begin{array}{l}\text { Okul çağı } \\
7 \text { yaş ve üstü }\end{array}$ & $319(73.7)$ & $\begin{array}{l}\text { Acil } \\
\text { Ertelenemeyen }\end{array}$ & 306 & $\begin{array}{l}\text { Appendisit } \\
\text { Akut scrotum } \\
\text { Malignite } \\
\text { Özofagus darlığı/ dilatasyon }\end{array}$ & $\begin{array}{c}260 \\
17 \\
5 \\
3 \\
\end{array}$ & $\begin{array}{r}4 \\
0.9 \\
0 \\
0\end{array}$ \\
\hline
\end{tabular}




\section{TARTIŞMA}

Çalışmamız, acil ve ertelenemeyen cerrahi nedenlerle bir COVID-19 pandemi hastanesi çocuk cerrahi kliniğine başvuran olguların PCR sonuçlarını, COVID-19 pozitifliğinin komplikasyonlara etkisini sunmaktadır. Pandeminin erken dönemlerinde çocuk hastalarda bu tip operasyonların yapılma gerekliliği ve beraberinde sağlık çalışanlarının korunma zorunluluğu asemptomatik hastalık prevalansını daha önemli kılmıştır. Bu prospektif çalışma ile acil veya ertelenemeyen cerrahi planlanan asemptomatik çocuklarda düşük COVID-19 PCR pozitifliği (\%0,9 prevalans) tespit edilmiştir. Ameliyat öncesi incelemeler esnasında saptanan mevcut prevalans değeri kısıtlı sayıda çocuk verisiyle benzer olup erişkinlere ait düşük sürveyans oranları ile beraber güvenli prosedür uygulamalarının planlanmasına ışık tutacağı kanaatindeyiz(4, 5). Ancak saptanan düşük prevalans değerine rağmen pozitif vakaların tümünün asemptomatik oluşu, her bireye pozitif olabilir intimali ile yaklaşarak gerekli korunma tedbirlerinin alınması gereğini ortaya koymaktadır.

Güncel bilgiler COVID-19'un \%5 ila \%75 oranında asemptomatik olabileceğini ve bu esnada bulaştırıcılık riskinin devam ettiğini göstermektedir(4). Mart 2020 itibariyle COVID-19 polimeraz zincir reaksiyonu (PCR) testi, sadece semptomatik hastalar, sağlık çalışanları veya ortak bakım merkezlerinde yapılabildiği için topluma ait asemptomatik viral hastalık taşıyıcılığı verileri sınırlıydı. Ayrıca COVID-19'un cerrahi nedenden bağımsız solunum yolu komplikasyonlarına ve \%19'a varan perioperatif mortalite intimaline dikkat çekilmekteydi(6). Şiddetli Akut Solunum Sendromu Coronavirüs 2'nin (SARS-CoV-2) etkilediği ilk olgulardan bu güne asemptomatik vakaların tüm dünyaya hızla yayılımı konusunda önemli rol oynadıkları bilinmektedir. Çocuklarda yapılan incelemede COVID-19 enfeksiyonunun \%94 oranında asemptomatik veya hafif seyirli olduğu saptanmıştır(7). COVID-19 için belirtiler tarafımızdan sorgulansa da kısıtlı sayıda COVID-19 PCR pozitif olgunun hiçbirini bu şekilde saptayamamış oluşumuz genelde çocuklarda enfeksiyonun asemptomatik oluşuyla ilişkili olabilir. Semptom sorgulaması da yapılan bir preoperatif incelemeye ait veriler PCR pozitifliği saptanan olguların en az yarısında belirtilerin olmadığını göstermektedir (5).

Erişkinlerde cerrahi sebebe ek olarak COVID-19 varlığı akciğer problemlerini yarı yarıya arttırırken ve acil cerrahi nedenlerin mortalite için önemli bir risk faktörü olduğu bildirilmiştir (6). Oysaki çocuklarda perioperatif COVID-19 enfeksiyonu, erişkinlere nazaran oldukça düşük oranda morbiditeye ve mortaliteye neden olmaktadır. Bu durumdan da yaşla artan ek patolojiler sorumlu tutulmuştur (8). Serimizde PCR pozitifliği saptanan hiçbir olguda COVID-19 ilişkili komplikasyon ya da sağlık çalışanlarına ispat edilen bulaş olmaması, koruma önlemlerinin etkinliğini, acil cerrahi organizasyonuna izin verirken sağlık çalışanlarına bulaşın oluşturduğu riskin beklenenden düşük olduğunu göstermektedir. Ancak literatürde de cerrahi ekiplerin hastane kaynaklı COVID-19 bulaşı açısından ikinci sıklıkta yer aldığı bildirilmiştir (9). Zira, pozitif olguların tümünün asemptomatik oluşu korunma tedbirlerine uyulsa da sağlık çalışanlarına bulaş riskini gündeme getirmektedir. Ayrıca asemptomatik olguda PCR bakılması, COVID-19 pozitifliğini saptayarak olası preoperatif ve postoperatif komplikasyon açısından klinisyeni daha dikkatli olmaya yönlendirebilir.

COVID-19 tüm yaş gruplarını etkileyebilse de erişkin ve çocuğun beraber değerlendirildiği serilerde çocuk oranı anlamlı şekilde düşük bulunmuştur (10). Geniş bir seriye ait veride ancak \%1'lik popülasyonu 14 yaş altı çocukların oluşturduğu saptanmıştır (11). Ancak COVID-19 yaş gözetmeden yenidoğandan on sekiz yaşına tüm çocukları etkileyebilmektedir (12). Serimizde tüm PCR pozitif olguların akut apandisit nedeniyle opere edilen okul çağı çocuklar oluşu patolojinin sıklığı ve en sık etkilediği yaş grubuyla ilişkili olduğu düşünüldü. Çok merkezli yapılmış bir çocuk çalışmasında pozitif vakaların yaşlarının daha büyük oluşu istatistiksel olarak anlamlı bir risk faktörü olarak tespit edilmiştir. Serimizde ise pozitif vakaların yaş ortalamasının nispeten büyük oluşu dikkati çekici bulunmuştur. Ancak komplikasyon gelişimi yönünden değerlendirildiğinde etken ve yaşın peroperatif komplikasyonlara katkısı saptanmamıştır.

Bu çalışmanın bazı kısıtlamaları mevcuttur. Çalışmamız tek merkezli ve altı aylık süreci kapsayan kesitsel bir incelemedir. Gelecekteki çalışmalar daha uzun vadeli ve hasta merkezli sonuçları değerlendirmelidir. Fakat birçok merkezde PCR tetkiki yapılamaz iken kliniğimizde yapılan PCR incelemeleri pandeminin erken verilerini yansıtmaktadır. Tek PCR değerlendirmesinin yalancı negatiflik oranları da göz önünde bulundurulmalıdır. Gelecekteki yapılacak çalışmaların, ameliyat için hasta değerlendirmesinde tek ya da çoklu test gerekliliği, yalancı pozitiflik ve negatiflik oranları ile ilgili önerilerde bulunması faydalı olacaktır kanaatindeyiz.

Çalışmamız, prospektif olarak asemptomatik çocuk olguların acil ve ertelenemeyen ameliyatlar öncesi düşük COVID-19 PCR pozitifliğini ve düşük komplikasyon oranını ortaya koyan bir araştırma olup kontaminasyon riskinin en aza indirilmesine ve sağlık çalışanlarını korunmasında gerekli önlemlerin alınmasına ışık tutacağı kanaatindeyiz.

\section{KAYNAKLAR}

1. Dedeilia A, Esagian SM, Ziogas IA, Giannis D, Katsaros I, Tsoulfas G. Pediatric surgery during the COVID-19 pandemic. World J Clin Pediatr 2020;9:7-16.

2. Saxena AK. SARS-CoV-2 pandemic and pediatric endoscopic surgery. Springer 2020;2:51-3.

3. Azılı MN, Şenel E. Management of Trauma And Surgical Procedures in Children During The COVID-19 Pandemic. Türkiye Çocuk Hast Derg 2020;14(COVID-19):72-5. 
4. Singer JS, Cheng EM, Murad DA, Maurice AdS, Hines OJ, Uslan DZ, et al. Low prevalence (0.13\%) of COVID-19 infection in asymptomatic pre-operative/pre-procedure patients at a large, academic medical center informs approaches to perioperative care. Surgery 2020;168:980-6.

5. Lin EE, Blumberg TJ, Adler AC, Fazal FZ, Talwar D, Ellingsen K, et al. Incidence of COVID-19 in pediatric surgical patients among 3 US children's hospitals. JAMA surgery 2020;155:775-7.

6. Nepogodiev D, Bhangu A, Glasbey JC, Li E, Omar OM, Simoes JF, et al. Mortality and pulmonary complications in patients undergoing surgery with perioperative SARS-CoV-2 infection: an international cohort study. The Lancet 2020;396:27-38.

7. Robbins E, Ilahi Z, Roth P. Febrile infant: COVID-19 in addition to the usual suspects. Pediatr Infect Dis J 2020;39:e81-e2.
8. Nepogodiev D. Favourable perioperative outcomes for children with SARS-CoV-2. Journal of British Surgery 2020;107:e644-e5.

9. Gomez Ochoa SA, Franco OH, ROJAS LZ, Raguindin PF, Roa Diaz ZM, Wyssamnn BM et al. COVID-19 in Health-Care Workers: A Living Systematic Review and Meta-Analysis of Prevalence, Risk Factors, Clinical Characteristics, and Outcomes. Am J Epidemiol 2021;190:161-75.

10. Yang Y, Lu Q, Liu M, Wang Y, Zhang A, Jalali N, et al. Epidemiological and clinical features of the 2019 novel coronavirus outbreak in China. medrxiv. 2020. doi.org/10.1101/2020.02.10.20021675.

11. Wu Z, McGoogan JM. Characteristics of and important lessons from the coronavirus disease 2019 (COVID-19) outbreak in China: summary of a report of 72314 cases from the Chinese Center for Disease Control and Prevention. Jama 2020;323:1239-42.

12. Jiatong $S$, Wenjun L. Epidemiological characteristics and prevention and control measures of Corona Virus Disease 2019 in children. J Trop Med 2020;20:153-6. 